\title{
STRATEGI PENGEMBANGAN MODEL PEMASARAN BERAS ORGANIK BERBASIS CONSUMER'S MARKET DI KABUPATEN BANYUMAS
}

\author{
Anny Hartati dan Dindy Darmawati Putri \\ Staf Pengajar Program Studi Sosial Ekonomi Pertanian/Agribisnis \\ Fakultas Pertanian Universitas Jenderal Soedirman Purwokerto \\ E-mail : hartati.anny@gmail.com.
}

\begin{abstract}
At present, many farmer groups at Banyumas Regency are cultivating organic rice. Their activities are very progressive. They distribute at Baturraden, Sumbang, Kedungbanteng, and Pekuncen. The activities are closed relation in the market. There is trend in moving from seller's merket to consumer's market. The market is not determined by middle trader, but end product consumer (consumers driven). In the case, consumer's require complete information about physical, chemical and biological characters of product. Therefore, producers must enclose liable information on labels. The goals of research were to analyze farming activity of organic rice, and study on consume's preferences. Survey method was used, followed descriptive-qualitative analysis, and principal component analysis (PCA) for finding out factors affecting consumers in buying organic rice and consuming the products based on profile and character of consumers. The research showed that (1) organic rice cultivation was profitable; (2) Attributes of organic rice consisting of price, flavor, availability, and guarantee of product are important; (3) Consumers are satisfied to the organic rice producer's perfomance in determining price and flavor. We recommend to the producer for maintenance of quality (flavour), availability and guarantee of product.
\end{abstract}

Keywords : development strategy, consumer's market, marketing model, organic rice.

\begin{abstract}
Abstrak: Saat ini di Kabupaten Banyumas telah banyak kelompok tani yang membudidayakan padi organik, perkembangannya pun sangat pesat diantaranya di kecamatan Pekuncen, Kecamatan Baturaden, Kecamatan Sumbang, dan Kecamatan Kedung bateng. Penelitian ini bertujuan untuk menganalisis preferensi konsumen beras organik untuk pengembangan model pemasaran beras organik. Penelitian ini menggunakan deskriptif analisis dan Principal Component Analysis (PCA). Data diperoleh dengan metode survey di empat kecamatan yaitu kecamatan Pekuncen, Kecamatan Baturaden, Kecamatan Sumbang, dan Kecamatan Kedung bateng. Hasil penelitian menunjukkan bahwa (1) Pertanian padi organik menguntungkan (profitable); (2) atribut yang berpengaruh harga, rasa, ketersediaan produk dan keterjaminan produk; (3) konsumen puas dengan kinerja produsen dalam menentukan harga beras organiknya dan puas dengan cita rasa beras organiknya; sementara variabel ketersediaan produk dan keterjaminan produk menghasilkan kepuasan yang cukup. Kami merekomendasikan kepada produsen untuk meningkatkan kualitas rasa, ketersediaan produk dan keterjaminan produk.
\end{abstract}

Kata Kunci : pengembangan, preferensi, konsumen, pemasaran, organik

\section{PENDAHULUAN}

Pembangunan pertanian Indonesia sudah saatnya di arahkan tidak sekedar memproduksi komoditi, tetapi juga mampu menciptakan nilai tambah (value added) yang didasari peluang dan potensi pasar. Salah satu pasar yang potensial saat ini adalah pasar komoditas 
organik termasuk beras. Faktor pendorong adanya pertanian organik adalah aspek kualitas bahan konsumsi untuk kesehatan jangka panjang manusia, aspek penyelamatan dan kelestarian lingkungan (environmentally friendly and farming sustainability), aspek ideologis, dan aspek nilai tambah secara ekonomi.

Perkembangan produksi dan pemasaran produk pertanian organik di Indonesia cukup pesat sekitar $10 \%$ per tahun (Indro Surono, 2005 dalam Mayasari, 2009). Perkembangan ditandai dengan semakin banyaknya supermarket, outlet, dan model pemasaran alternatif di berbagai kota yang menjual produk organik. Perkembangan juga tergambar dari semakin banyaknya organisasi non pemerintah sebagai pendamping petani atau kelompok tani atau perusahaan swasta yang mengembangkan pertanian organik.

Beras organik merupakan produk pertanian padi dengan sistem budidaya organik. Beras organik sangat baik bagi kesehatan karena bebas dari bahan kimia berbahaya dibandingkan beras konvensional yaitu mempunyai aroma khas alami, tidak mudah berair, rasanya enak dan tidak cepat basi. Hal ini menjadikan beras organik semakin banyak disukai konsumen (Sutrisno, 1999).

Saat ini Kabupaten Banyumas telah banyak kelompok tani yang membudidayakan padi organik, perkembangannya pun sangat pesat diantaranya di Kecamatan Baturraden, Sumbang, Kedungbanteng dan Pekuncen. Kemajuan pertanian organik tidak terlepas dari faktor pasar dalam hal ini konsumsi. Globalisasi dan perkembangan iptek mendorong perubahan besar dan cepat pada sifat, struktur dan perilaku pasar barang-barang konsumen terutama produk pertanian, hal inilah yang disebut revolusi pemasaran. Saat ini sifat pasar bergeser dari pasar penjual (seller's market) atau pasar pembeli (buyer's market) ke pasar konsumen (consumer's market). Dengan perkataan lain fundamental pasar tidak lagi ditentukan oleh pedagang perantara jual beli, tetapi ditentukan oleh konsumen akhir produk (consumer's driven). Pada gilirannya revolusi pemasaran tersebut menimbulkan tantangan bagi para produksi beras organik. Salah satu tantangannya bagaimana membangun keunggulan daya saing (competitive advantage) beras organik sampai ke tingkat mikro agar produknya terserap pasar antara lain dengan terpenuhinya kemampuan untuk mengungkap dan memenuhi preferensi konsumen sehingga produsen dapat menentukan strategi pemasaran sesuai dengan consumer's market dengan mempertimbangkan tiga faktor utama yaitu : Brand, Product, and Consumer.

Menurut Wibowo dkk, 2007, preferensi konsumen saat ini telah bergeser dari atribut rinci fisika-kimia atau dari pemenuhan rasa ke pemenuhan fungsi, untuk produk pangan konsumen semakin mengutamakan kandungan gizi dan kesehatan, jadi bukan sekedar rasa dan citra dari produk tersebut. Saat ini konsumen tidak lagi membeli komoditi yang bersifat homogen, tetapi produk dengan atribut spesifik. Hal tersebut akibat meningkatnya kesadaran dan kebutuhan keamanan (product savety) barang konsumsi. Konsumen menuntut informasi yang lengkap dan transparan mengenai ciri-ciri fisika, kimia dan biologi dari produk, sehingga produk perlu dilengkapi dengan keterangan terpercaya antara lain labelisasi. Menurut Rusma dkk, 2011 komponen utama dalam proses pengambilan keputusan pembelian beras organik meliputi mutu, promosi, harga, rasa, dan pengaruh teman atau keluarga. Dengan demikian diperlukan strategi pemasaran seperti strategi produk berupa perbaikan kualitas, strategi harga, strategi promosi, dan strategi distribusi.

Atas dasar latar belakang masalah tersebut, perlu dikaji strategi pengembangan model pemasaran beras organik berbasis consumer's market di Kabupaten Banyumas yang dilakukan dua tahap atau dua tahun. Sekarang baru dilakukan tahun pertama, sedangkan tahun kedua mudah-mudahan segera diberi biaya sehingga dapat berlanjut.

Tujuan penelitian pada tahun pertama yaitu : (1) Menganalisis finansial usahatani beras organik, (2) Melakukan kajian preferensi konsumen, dan (3) Menganalisis strategi pemasaran. Adapun penelitian kedua yaitu : (1) Melakukan transfer pengetahuan tentang brand, kualitas produk dan perilaku konsumen tentang beras organik kepada produsen, (2) Melakukan pendampingan perbaikan mutu, brand, kualitas sesuai permintaan pasar dan labelisasi, dan (3) Membuat model penentuan kesediaan konsumen untuk membeli beras organik. Penelitian ini diharapkan bermanfaat yaitu : (1) Memberikan informasi pasar kepada produsen 
beras organik, (2) Menemukan model pengembangan pemasaran beras organik, (3) Meningkatkan brand dan kualitas beras organik, dan (4) Memberikan informasi kepada lembaga terkait dalam membuat kebijakan.

\section{METODOLOGI PENELITIAN}

Metode dasar penelitian ini adalah survai dengan metode pengambilan sampel daerah dilakukan secara purposive karena di Kabupaten Banyumas terdapat empat kecamatan yang melaksanakan usahatani padi organik. Selanjutnya diambil desa-desa yang melaksanakan usahatani padi organik dan diambil semua (sensus) petani yang melaksanakan usahatani padi organik sejumlah 35 petani. Metode pengambilan data dengan teknik wawancara, pencatatan dan pengamatan langsung di lapangan. Jenis data yang digunakan adalah data primer dan sekunder yang dilengkapi dengan daftar pertanyaan yang dipersiapkan sebelumnya. Metode analisis data yang digunakan adalah deskriptif kualitatif dan dianalisis dengan komponen utama Principal Component Analysis atau PCA yang merupakan bagian dari Metode Analisis Sidik Peubah Ganda (Multivariate Analysis). Selain itu juga dilakukan Uji Validitas dan Reliabilitas yang masing-masing untuk mengetahui apakah item pertanyaan dalam daftar pertanyaan mampu mengukur respons petani dan dapat diandalkan. Rumus yang digunakan pada uji validitas adalah Product Moment (Singarimbun dan Effendi, 1989) dengan derajat kebebasan (n-2) dan $\alpha=0,05$.

$$
r_{\text {hit }}=\frac{N \sum X Y-\left(\sum X\right)\left(\sum Y\right)}{\sqrt{\left\{N \cdot \sum X^{2}-\left(\sum X\right)^{2}\right)\left\{N \sum Y^{2}-\left(\sum Y\right)^{2}\right\}}}
$$

Keterangan :

$\mathrm{X}=$ Skor responden pada masingmasing pernyataan

$\mathrm{Y}=$ Skor total

$\mathrm{N}=$ Jumlah responden

Bila $r_{\text {hit }} \geq r_{\text {tabel }}$, berarti pernyataan valid. Bila $r_{\text {hit }}<r_{\text {tabel }}$, berarti pernyataan tidak valid.

Pengujian reliabilitas dilakukan dengan metode genap ganjil. Rumus yang digunakan adalah :

$$
r_{h i t}=\frac{N \sum X Y-\left(\sum X\right)\left(\sum Y\right)}{\sqrt{\left\{N \cdot \sum X^{2}-\left(\sum X\right)^{2}\right)\left\{N \sum Y^{2}-\left(\sum Y\right)^{2}\right\}}}
$$

Keterangan :

$\mathrm{r}=$ Koefisien Korelasi Product

Moment

$\mathrm{X}=$ Nilai valid nomor ganjil

$\mathrm{Y}=$ Nilai valid nomor genap

$\mathrm{N}=$ Jumlah responden

Selanjutnya reliabilitas diuji dengan rumus Spearman Brown :

Keterangan

$$
R \mathrm{xy}=\frac{2 \mathrm{R}}{1+R}
$$

Rxy $=$ Koefisien reliabilitas

$\mathrm{R} \quad=$ Koefisien Korelasi Product

Moment

Bila $\mathrm{Rxy} \geq \mathrm{R}_{\text {tabel, }}$, berarti kuesioner memenuhi syarat reliabilitas.

Bila Rxy < $\mathrm{R}_{\text {tabel}}$, berarti kuesioner tidak memenuhi syarat reliabilitas.

Selain metode analisis tersebut, digunakan juga metode Likert's Summated Rating (LSR) untuk minta kepada responden atas setuju tidaknya terhadap isi pernyataan dengan lima kategori yaitu Sangat Tidak Setuju (STS), Tidak Setuju (TS), Tidak Tahu atau Netral (N), Setuju (S), dan Sangat Setuju (SS) dengan kriteria sikap :

- Jika jumlah skor dibawah nilai kuartil I berarti sikap sangat negatif.

- Jika jumlah skor tepat berada di nilai kuartil I sampai dengan di bawah nilai median berarti sikap negatif.

- Jika jumlah skor berada tepat di nilai median sampai dengan di bawah nilai kuartil III berarti sikap positif.

- Jika jumlah skor berada tepat atau di atas nilai kuartil III berarti sikap sangat positif.

Hasil yang diperoleh dari pengukuran dengan Skala Likert's masih dalam bentuk skala pengukuran ordinal, sehingga hasil skala yang diperoleh tidak dapat dicari selisih antara tanggapan satu dengan yang lain dan sikap populasi terhadap variabel tidak dapat diramalkan. Oleh karena itu untuk menginterpretasikan. Hasil pengukuran skala ordinal dilanjutkan dengan pengukuran skala interval dengan metode Successive Interval dengan langkah :

1. Menentukan frequensi setiap skor pada setiap variabel. 
2. Menentukan proporsi setiap skor pada setiap variabel dengan rumus:

Keterangan :

$$
P_{i}=\frac{f_{i}}{f_{\text {total }}}
$$

$P_{i} \quad=$ Proporsi ke $i$

$f_{i} \quad=$ Frekuensi ke $i$

$f_{\text {total }}=$ Jumlah frekuensi keseluruhan

3. Menentukan proporsi kumulatif

4. Menentukan nilai Scale Value (SV) dengan rumus :

SV

$=\frac{\text { Density batas rendah }- \text { Density batas tertinggi }}{\text { Daerah batas bawah tertinggi }- \text { Daerah batas bawah terendah }}$

\section{HASIL DAN PEMBAHASAN}

\section{Rata-rata Biaya, Penerimaan dan Pendapatan Bersih Usahatani Padi Organik.}

Rata-rata biaya, penerimaan dan pendapatan bersih usahatani padi organik dapat dilihat pada Lampiran 1. Berdasarkan Lampiran 1, dapat diketahui bahwa rata-rata penerimaan usahatani padi organik per luas garapan 0,33 hektar sebesar Rp.6.625.171 dengan total biaya sebesar Rp.2.420.813, sehingga diperoleh pendapatan bersih sebesar Rp.4.204.358. Adapun rata-rata penerimaan usahatani padi organik per hektar sebesar Rp.20.076.276 dengan total biaya sebesar Rp.7.335.797, pendapatan bersih sebesar Rp.12.740.479 dan $\mathrm{BC}$ ratio sebesar 1,74. Dengan demikian dapat dikatakan bahwa usahatani padi organik memberikan pendapatan bersih atau keuntungan cukup besar.

\section{Preferensi Konsumen}

a. Uji Validitas
Rumus yang digunakan adalah Korelasi Product Moment. Hasil uji validitas dapat dilihat pada Lampiran 2 sampai dengan 11, dapat diketahui bahwa $r$ hitung korelasi pernyataan dari setiap atribut lebih besar daripada nilai kritis ( $\mathrm{r}$ tabel) sebesar 0,2787 pada tingkat kepercayaan 95 persen, sehingga seluruh item pernyataan pada daftar pertanyaan dinyatakan valid.

\section{b. Uji Reliabilitas}

Rumus yang digunakan adalah Alpha Cronbach. Hasil uji reliabilitas dapat dilihat pada Lampiran 12 dan 13. Berdasarkan Lampiran 12 dan 13, dapat diketahui bahwa $\mathrm{r}$ hitung korelasi pernyataan dari setiap atribut lebih besar daripada nilai kritis ( $\mathrm{r}$ tabel) sebesar 0,2787 pada tingkat kepercayaan 95 persen, sehingga semua item pernyataan setiap atribut dinyatakan reliabel.

\section{Harapan Konsumen dan Kinerja Produsen Terhadap Baras Organik.}

Salah satu hal yang sangat penting dalam memahami harapan konsumen dan kinerja produsen adalah masalah pengungkapan atau pengukuran. Respons individu terhadap pernyataan harapan konsumen dan kinerja produsen yang berupa jawaban setuju atau tidak setuju menjadi indikator harapan konsumen dan kinerja produsen. Pengukuran indikator variabel kualitatif menggunakan metode Likert Summated Ratings.

Dalam hal ini variabel yang diukur harga, cita rasa, kemasan, ketersediaan produk dan keterjaminan produk. Hasil analisis tentang harapan konsumen dan kinerja produsen terhadap atribut beras organik dapat dilihat pada Tabel 1 dan Tabel 2.

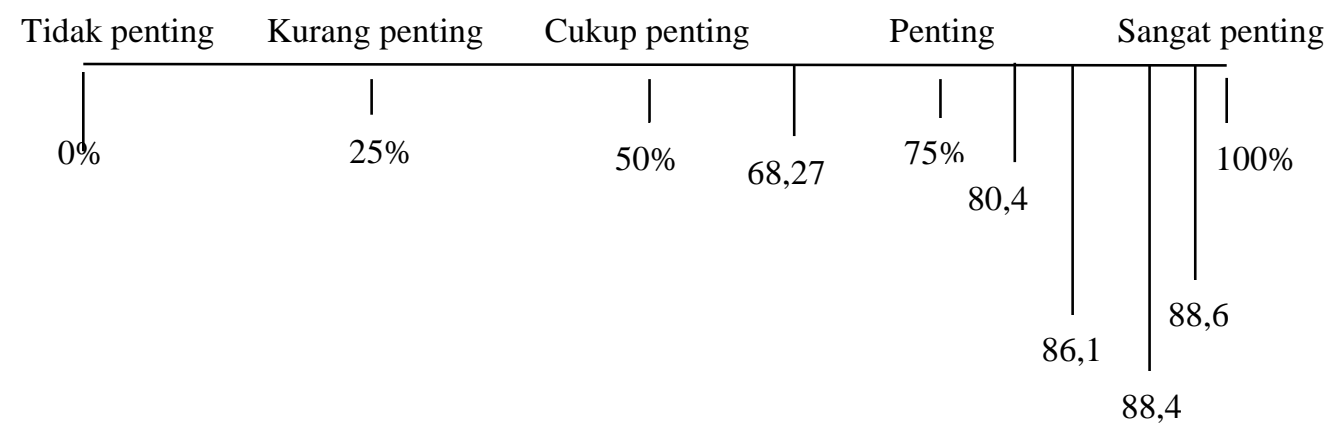

Gambar 1. Atribut harga, cita rasa, ketersediaan, produk, dan keterjaminan produk beras organik adalah penting 
Anny Hartati dan Dindy Darmawati P. : Strategi Pengembangan Model Pemasaran...

Tabel 1. Harapan konsumen terhadap atribut beras organik

\begin{tabular}{cccccc}
\hline No. & $\begin{array}{c}\text { Atribut beras } \\
\text { Organik }\end{array}$ & $\begin{array}{c}\text { Range } \\
\text { skor } *)\end{array}$ & Skor & Persentase & Keterangan \\
\hline 1. & Harga & $0-750$ & 663 & 88,4 & Penting \\
2. & Cita Rasa & $0-1000$ & 804 & 80,4 & Penting \\
3. & Kemasan & $0-750$ & 512 & 68,27 & Cukup Penting \\
4. & Ketersediaan Produk & $0-500$ & 443 & 88,6 & Penting \\
5. & Keterjaminan Produk & $0-1000$ & 861 & 86,1 & Penting \\
\hline
\end{tabular}

Sumber : Data primer diolah, 2014

Tabel 2. Kinerja produsen terhadap atribut beras organik

\begin{tabular}{cccccc}
\hline No. & Atribut beras organik & $\begin{array}{c}\text { Range skor } \\
*)\end{array}$ & Skor & Presentase & Keterangan \\
\hline 1. & Harga & $0-750$ & 575 & 76,67 & Puas \\
2. & Cita rasa & $0-1000$ & 784 & 78,4 & Puas \\
3. & Kemasan & $0-750$ & 456 & 61 & Cukup puas \\
4. & Ketersediaan produk & $0-500$ & 355 & 71 & Cukup puas \\
5. & Keterjaminan produk & $0-1000$ & 717 & 71,7 & Cukup puas \\
\hline
\end{tabular}

Sumber : Data primer diolah, 2014

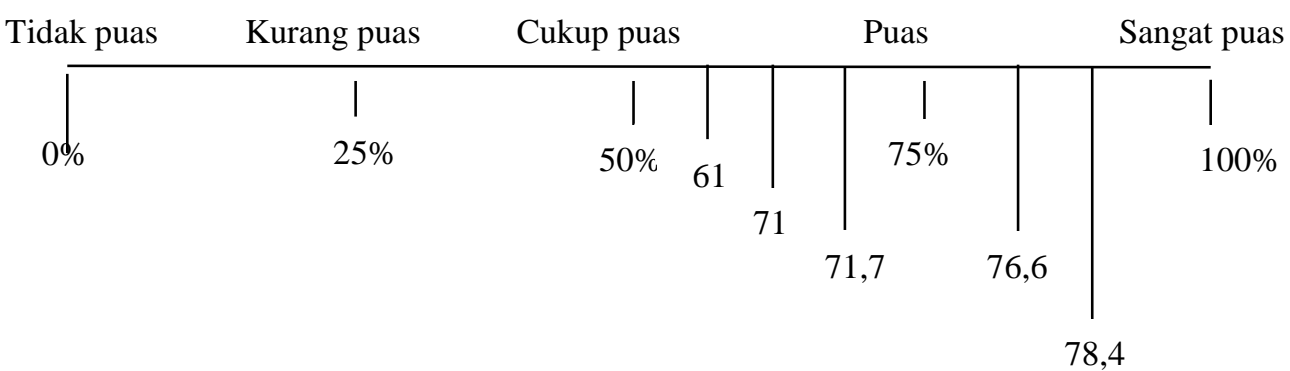

Gambar 2. Atribut harga dan cita rasa beras organik

Berdasarkan Tabel 1, konsumen beras organik di Kabupaten Banyumas menyatakan bahwa atribut harga, cita rasa, ketersediaan produk dan keterjaminan produk penting untuk diperbaiki agar konsumen semakin percaya terhadap produsen, sedangkan untuk atribut kemasan, konsumen hanya menilai cukup penting. Artinya, konsumen tidak terlalu mempersoalkan kemasan dari beras organik.

Keterangan : Perhitungan *) range skor adalah nilai skor likert $\mathrm{x}$ jumlah item valid $\mathrm{x}$ banyaknya responden per kelompok (Hariadi, 2011). Secara kontinum, dapat dijelaskan pada Gambar 1.

Berdasarkan Tabel 2, konsumen beras organik di Kabupaten Banyumas menyatakan bahwa atribut harga dan cita rasa, adalah puas. Artinya, konsumen puas dengan kinerja produsen dalam menentukan harga beras organik dan puas dengan cita rasa beras organik, sedangkan untuk atribut kemasan, ketersediaan produk dan keterjaminan produk, konsumen hanya menilai cukup puas. Artinya, konsumen hanya merasa cukup puas dengan kemasan, ketersediaan dan keterjaminan beras organik.

Keterangan : Perhitungan *) range skor adalah nilai skor likert $\mathrm{x}$ jumlah item valid $\mathrm{x}$ banyaknya resonden per kelompok (Hariadi, 2011). Secara kontinum, dapat dijelaskan pada Gambar 2.

\section{KESIMPULAN DAN SARAN}

\section{Kesimpulan}

Dari hasil penelitian dan pembahasan dapat ditarik kesimpulan sebagai berikut:

1. Usahatani padi organik di Kabupaten Banyumas menguntungkan yaitu sebesar Rp.12.740.479 per hektar per musim tanam.

2. Harapan konsumen terhadap atribut beras organik yang meliputi harga, cita rasa, 
ketersediaan produk, dan keterjaminan produk adalah penting.

3. Konsumen beras organik menyatakan puas dengan kinerja produsen dalam menentukan harga dan cita rasa beras organik.

\section{Saran}

Dari hasil penelitian, pembahasan dan kesimpulan dapat diberikan saran sebagai berikut : Perlu ditingkatkan kinerja produsen beras organik baik dari segi cita rasa, ketersediaan produk maupun keterjaminan produk walaupun harga lebih mahal.

\section{DAFTAR PUSTAKA}

Mayasari, L. 2009. Analisis Balanced Scorecard Dalam Strategi Pengembangan Produksi Dan Pemasaran Beras Organik Pada Kelompok Tani Cibereum Jempol Kelurahan Mulyaharja, Kecamatan Bogor Selatan Kota Bogor. Skripsi Institut Pertanian Bogor. (Tidak dipublikasikan)
Rusma, J., M. Hubies dan B. Suharjo. 2011. Kajian Preferensi Konsumen Rumah Tangga Terhadap Beras Organik di Wilayah Kota Bogor. Jurnal Manajemen IKM Volume VI No.1 (49-54).

Simamora, B. 2004. Panduan Riset Perilaku Konsumen. PT. Gramedia Pustaka Utama, Jakarta.

Singarimbun, M. dan S. Effendi, 1989. Metode Penelitian Survei. LP3ES. Jakarta.

Sutrisno. 1999. Pertanian pada Abad 21. Dirjen Perguruan Tinggi. Departemen Pendidikan dan Kebudayaan. Jakarta.

Wibowo, P., S.D Indrasari, dan D.D. Handoko. 2007. Preferensi Konsumen Karakteristik Beras dan Kesesuaiannya dengan Standar Mutu Beras di Jawa Tengah. Prosiding Apresiasi Hasil Penelitian Padi. 
Anny Hartati dan Dindy Darmawati P. : Strategi Pengembangan Model Pemasaran...

Lampiran 1. Rata-rata biaya, penerimaan, dan pendapatan usahatani padi organik petani

\begin{tabular}{|c|c|c|c|}
\hline No & Uraian & $\begin{array}{c}\text { Per Luas Lahan } \\
\text { Garapan }\end{array}$ & Per Hektar \\
\hline \multirow[t]{2}{*}{1} & Penerimaan & & \\
\hline & Total Penerimaan & 6.625 .171 & 20.076 .276 \\
\hline \multirow[t]{13}{*}{2} & Biaya Produksi & & \\
\hline & a. Biaya Tetap & & \\
\hline & Sewa Lahan & 1.108 .286 & 3.358 .442 \\
\hline & Penyusutan Alat & 57.537 & 174.355 \\
\hline & b. Biaya Variabel & & \\
\hline & 1) Bibit & 170.371 & 516.276 \\
\hline & 2) Pupuk Organik & 118.011 & 357.609 \\
\hline & 3) Pupuk Anorganik & 15.436 & 46.776 \\
\hline & 4) Pestisida Organik & 2.786 & 8.442 \\
\hline & 5) Pestisida Anorganik & 6.957 & 21.082 \\
\hline & 6) Tenaga Kerja & 941.429 & 2.852 .815 \\
\hline & 7) Sewa Alat & 302.365 & 916.258 \\
\hline & Total biaya & 2.420 .813 & 7.335 .797 \\
\hline 3 & Pendapatan Bersih & 4.204 .358 & 12.740 .479 \\
\hline 4 & $\mathrm{BC}$ ratio & 1,74 & \\
\hline
\end{tabular}

Sumber : Data primer diolah, 2014

Lampiran 2. Hasil uji validitas atribut harapan terhadap harga

\begin{tabular}{cccc}
\hline No. Pernyataan & r hitung & r tabel & Keterangan \\
\hline 1 & 0,723 & 0,2787 & Valid \\
2 & 0,788 & 0,2787 & Valid \\
3 & 0,656 & 0,2787 & Valid
\end{tabular}

Sumber : Data primer diolah, 2014

Lampiran 3. Hasil uji validitas atribut harapan terhadap cita rasa

\begin{tabular}{cccc}
\hline No. Pernyataan & r hitung & r tabel & Keterangan \\
\hline 4 & 0,549 & 0,2787 & Valid \\
5 & 0,706 & 0,2787 & Valid \\
6 & 0,772 & 0,2787 & Valid \\
7 & 0,446 & 0,2787 & Valid \\
\hline
\end{tabular}

Sumber : Data primer diolah, 2014

Lampiran 4. Hasil uji validitas atribut harapan terhadap kemasan

\begin{tabular}{cccc}
\hline No. Pernyataan & r hitung & r tabel & Keterangan \\
\hline 8 & 0,780 & 0,2787 & Valid \\
9 & 0,888 & 0,2787 & Valid \\
10 & 0,869 & 0,2787 & Valid \\
\hline
\end{tabular}

Sumber : Data primer diolah, 2014 
Anny Hartati dan Dindy Darmawati P. : Strategi Pengembangan Model Pemasaran...

Lampiran 5. Hasil uji validitas atribut harapan terhadap ketersediaan produk

\begin{tabular}{cccc}
\hline No. Pernyataan & r hitung & r tabel & Keterangan \\
\hline 11 & 0,860 & 0,2787 & Valid \\
12 & 0,908 & 0,2787 & Valid \\
\hline
\end{tabular}

Sumber : Data primer diolah, 2014

Lampiran 6. Hasil uji validitas atribut kemasan

\begin{tabular}{cccc}
\hline No. Pernyataan & r hitung & r tabel & Keterangan \\
\hline 13 & 0,596 & 0,2787 & Valid \\
14 & 0,783 & 0,2787 & Valid \\
15 & 0,732 & 0,2787 & Valid \\
16 & 0,716 & 0,2787 & Valid \\
\hline
\end{tabular}

Sumber : Data primer diolah, 2014

Lampiran 7. Hasil uji validitas atribut kinerja terhadap harga

\begin{tabular}{cccc}
\hline No. Pernyataan & r hitung & r tabel & Keterangan \\
\hline 1 & 0,880 & 0,2787 & Valid \\
2 & 0,529 & 0,2787 & Valid \\
3 & 0,847 & 0,2787 & Valid \\
\hline
\end{tabular}

Sumber : Data primer diolah, 2014

Lampiran 8. Hasil uji validitas atribut kinerja terhadap cita rasa

\begin{tabular}{cccc}
\hline No. Pernyataan & r hitung & r tabel & Keterangan \\
\hline 4 & 0,543 & 0,2787 & Valid \\
5 & 0,498 & 0,2787 & Valid \\
6 & 0,805 & 0,2787 & Valid \\
7 & 0,678 & 0,2787 & Valid \\
\hline
\end{tabular}

Sumber : Data primer diolah, 2014

Lampiran 9. Hasil uji validitas atribut kinerja terhadap kemasan

\begin{tabular}{cccc}
\hline No. Pernyataan & r hitung & r tabel & Keterangan \\
\hline 8 & 0,915 & 0,2787 & Valid \\
9 & 0,931 & 0,2787 & Valid \\
10 & 0,891 & 0,2787 & Valid \\
\hline
\end{tabular}

Sumber : Data primer diolah, 2014

Lampiran 10. Hasil uji validitas atribut kinerja terhadap ketersediaan produk

\begin{tabular}{cccc}
\hline No. pernyataan & r hitung & r tabel & Keterangan \\
\hline 11 & 0,914 & 0,2787 & Valid \\
12 & 0,954 & 0,2787 & Valid \\
\hline
\end{tabular}

Sumber : Data primer diolah, 2014 
Anny Hartati dan Dindy Darmawati P. : Strategi Pengembangan Model Pemasaran...

Lampiran 11. Hasil uji validitas atribut kinerja terhadap keterjaminan produk

\begin{tabular}{cccc}
\hline No. pernyataan & r hitung & r tabel & Keterangan \\
\hline 13 & 0,926 & 0,2787 & Valid \\
14 & 0,944 & 0,2787 & Valid \\
15 & 0,961 & 0,2787 & Valid \\
16 & 0,947 & 0,2787 & Valid \\
\hline
\end{tabular}

Sumber : Data primer diolah, 2014

Lampiran 12. Hasil uji reliabilitas harapan konsumen

\begin{tabular}{cccc}
\hline Atribut & r hitung & r tabel & Keterangan \\
\hline Harga & 0,541 & 0,2787 & Reliabel \\
Cita Rasa & 0,476 & 0,2787 & Reliabel \\
Kemasan & 0,792 & 0,2787 & Reliabel \\
Ketersediaan Produk & 0,714 & 0,2787 & Reliabel \\
Keterjaminan Produk & 0,651 & 0,2787 & Reliabel \\
\hline
\end{tabular}

Sumber : Data primer diolah, 2014

Lampiran 13. Hasil uji reliabilitas kinerja produsen

\begin{tabular}{cccc}
\hline Atribut & r hitung & r tabel & Keterangan \\
\hline Harga & 0,630 & 0,2787 & Reliabel \\
Cita Rasa & 0,502 & 0,2787 & Reliabel \\
Kemasan & 0,898 & 0,2787 & Reliabel \\
Ketersediaan Produk & 0,835 & 0,2787 & Reliabel \\
Keterjaminan Produk & 0,959 & 0,2787 & Reliabel \\
\hline
\end{tabular}

Sumber : Data primer diolah, 2014 